\title{
PENGARUH IKLIM ORGANISASI DAN KETERLIBATAN KERJA TERHADAP OCB PEGAWAI
}

\section{THE INFLUENCE OF ORGANIZATIONAL CLIMATE AND WORK INVOLVEMENT ON OCB OF BPKAD EMPLOYEES}

\author{
Wirawan S. Pudjiomo ${ }^{1}$, Alimatus Sahrah ${ }^{2}$ \\ ${ }^{1}$ Universitas Tompotika Luwuk Kls. Ekstantion Banggai, ${ }^{2}$ Universitas Mercu Buana Yogyakarta \\ Pudjiomo.wirawan@gmail.com ${ }^{1}$, alimatus_sahrah@yahoo.co.id ${ }^{2}$
}

\begin{abstract}
Abstrak
Era globalisasi menuntut organisasi untuk mampu berkompetisi agar mampu tetap bertahan dalam persaingan global. Strategi untuk selalu dapat berkompetisi adalah dengan cara memperkuat kapasitas organisasi dan sumber daya manusia yang dimiliki. Upaya untuk memperkuat kapasitas organisasi dan SDM yang dimiliki adalah dengan memberikan perhatian khusus terkait dengan perilaku individu dalam organisasi agar mampu mencapai kinerja yang efektif dan efisien. Salah satu hal yang dibutuhkan oleh karyawan adalah perilaku prososial sering juga disebut sebagai Organizational Citizenship Behavior (OCB). Penelitian ini bertujuan untuk mengukur seberapa besar pengaruh iklim organisasi dan keterlibatan kerja terhadap OCB Pegawai BPKAD Kabupaten Banggai Laut Provinsi Sulawesi Tengah. Subjek dalam penelitian ini adalah pegawai BPKAD Kabupaten Banggai Laut Provinsi Sulawesi Tengah sebanyak 40 orang. Metode pengumpulan data menggunakan skala iklim organisasi, skala keterlibatan kerja, dan skala OCB. Analisis data dalam penelitian ini menggunakan teknik analisis regresi berganda. Hasil penelitian menunjukkan bahwa iklim organisasi berpengaruh positif dan signifikan terhadap OCB. Berdasarkan hasil penelitian dan pembahasan, maka dapat disimpulkan bahwa iklim organisasi dan keterlibatan kerja secara simultan maupun parsial berpengaruh signifikan terhadap OCB.
\end{abstract}

Kata Kunci: Iklim Organisasi, Keterlibatan Kerja, dan Organnization Citizenship Behavior.

\begin{abstract}
The globalization era requires organizations to be able to compete to survive in global competition. The strategy to always be able to compete is to strengthen the organization's capacity and human resources. The efforts to increase organizational capacity and human resources are by giving special attention related to individuals in the organization to be able to achieve an effective and efficient performance. One of the things needed by employees is pro-social, which is often called Organizational Citizenship Behavior (OCB). This study aims to measure the influence of organizational climate and work involvement on Organizational Citizenship Behavior of BPKAD Employee in Banggai Laut District, Central Sulawesi Province. The subjects in this study were 40 employees of BPKAD Banggai Laut District, Central Sulawesi Province. The method of data collection used organizational climate scale, job involvement scale, and Organizational Citizenship Behavior scale. Data analysis used multiple regression analysis technique. The results showed that organizational climate had a positive and significant effect on OCB. The results showed that the study had a positive and significant effect on OCB. Based on the results of research and discussion, it can be concluded that the organizational climate and work involvement simultaneously or partially had a positive and significant effect on $O C B$.
\end{abstract}

Keywords: Organizational Climate, Job Involvement, and Organization Citizenship Behavior

\section{PENDAHULUAN}

Pada era globalisasi saat ini, masalah sumber daya manusia masih menjadi sorotan bagi organisasi untuk dapat tetap bertahan dalam pasar kerja yang semakin kompetitif. Dalam konstelasi yang demikian, setiap organisasi dituntut mampu berkompetisi, sehingga dapat tetap bertahan 
dalam persaingan global. Strategi untuk selalu dapat berkompetisi adalah dengan cara memperkuat kapasitas organisasi dan sumber daya manusia yang dimiliki (Sudarmanto, 2014).

Dalam memperkuat kapasitas organisasi dan SDM yang dimiliki, hal yang seharusnya menjadi perhatian khusus oleh setiap organisasi salah satunya adalah perilaku individu dalam organisasi sehingga dapat mencapai kinerja yang efektif dan efisien. Sejalan dengan kinerja organisasi, Badan Pengelolaan Keuangan dan Aset Daerah atau disingkat BPKAD Kabupaten Banggai Laut Provinsi Sulawesi Tengah memiliki fungsi, diantaranya merumuskan kebijakan teknis di bidang pengelolaan keuangan dan aset, menyelenggarakan urusan pemerintahan di bidang pengelolaan keuangan, pelaksanaan kesekretariatan, serta pelaksanaan tugas lain yang diberikan oleh Bupati berkaitan dengan lingkup pengelolaan keuangan dan aset daerah.

Agar tugas dan fungsi BPKAD dapat dilaksanakan dengan maksimal, maka perlu peningkatan kinerja. Untuk itu, dalam meningkatkan kinerja diharapkan pegawai yang memiliki kemampuan berempati dalam bekerja. Kemampuan berempati merupakan manifestasi dari seorang pegawai sebagai makhluk sosial. Dengan empati, seseorang akan dapat memahami orang lain dan lingkungannya yang kemudian akan memunculkan perilaku sukarela menolong dan membentuk perilaku prososial (Howe, 2015). Perilaku prososial sering juga disebut sebagai Organizational Citizenship Behavior atau disingkat OCB dalam organisasi. OCB merupakan istilah lain dari perilaku kewargaan dalam organisasi. Hal ini seperti yang dinyatakan oleh Robbins dan Judge (2015), bahwa perilaku kewargaan merupakan perilaku diskresioner yang berkontribusi pada lingkungan psikologis dan sosial tempat kerja.

Menurut Murugesan, Raja, dan Kannan (2013), bahwa OCB termasuk "pro-sosial" atau perilaku etis diskresioner, sepertimembantu pegawai baru dalam organisasi, membantu rekan kerja, tidak menggunakan waktu istrahat dengan sia-sia, dan rela melakukan sesuatu pekerjaan diluar dari deskripsi yang ditetapkan. OCB didefinisikan Organ (dalam Kaswan, 2015) merupakan perilaku individu yang bersifat sukarela, tidak langsung diakui oleh system imbalan formal, dan secara keseluruhan meningkatkan efektifitas fungsi organisasi.

Sampai saat ini kasus OCB masih manjadi masalah dalam organisasi pada umumnya. Berdasarkan hasil observasi pada tanggal 24 sampai 26 september 2016 di BPKAD Kabupaten Banggai Laut Provinsi Sulawesi Tengah, terlihat bahwa sekitar 50\% lebih pegawai yang tidak membantu rekan kerja lain ketika pekerjaannya sudah selesai dengan hanya ditempat menunggu perintah atau tugas lain, yang kemudian mengartikan masih rendahnya aspek altruism dan conscientiousness dari OCB. Selanjutnya hasil wawancara yang dilakukan kepada 10 pegawai bahwa rata-rata mengeluh tentang pekerjaannya, yang kemudian mengartikan masih rendahnya aspek sportsmanship dari OCB, mereka merasakan suasana yang cenderung tertutup dan kurang berbagi informasi, yang kemudian mengartikan masih rendahnya aspek courtesy dari OCB, serta kurangnya diskusi antar pegawai khususnya tentang isu-isu untuk kemajuan BPKAD, yang kemudian mengartikan masih rendahnya aspek civic virtue dari OCB. 
Dalam bekerja, pegawai dalam organisasi seharusnya menciptakan kerjasama yang baik dengan saling membantu antara pegawai yang satu dengan yang lainnya atas dasar sifat sukarela, sehingga hal ini secara keseluruhan dapat meningkatkan kinerja yang efisien dan efektif. Penjelasan tersebut seperti yang dinyatakan Organ (dalam Kaswan, 2015) bahwa perilaku OCB bersifat sukarela, tidak diakui langsung oleh sistem imbalan formal, dan secara keseluruhan meningkatkan efektifitas fungsi organisasi. Lebih dari itu, OCB berdampak pada kinerja secara keseluruhan, baik itu kinerja individu dalam organisasi maupun kinerja organisasi (Kaswan, 2015).

Menurut Kaswan (2015), bahwa terdapat sejumlah faktor-faktor yang mempengaruhi OCB, diantaranya adalah karakteristik pekerjaan, kepribadian, sikap kerja yang meliputi keterlibatan kerja, motivasi, kepemimpinan, serta karakteristik kelompok dan organisasi yang meliputi iklim organisasi. Dari beberapa faktor tersebut, menarik untuk melihat pengaruh iklim organisasi dan keterlibatan kerja secara bersama-sama dalam menmpengaruhi OCB. terhadap OCB. Menurut Bianca dan Susihono (2012), bahwa istilah iklim organisasi pertama kali dipakai oleh Kurt Lewin pada tahun 1930-an, yang menggunakan istilah iklim psikologi. Lain halnya dengan Taguiri dan Litwin (dalam Soetopo, 2012) yang mengartikan iklim organisasi adalah suatu kualitas lingkungan internal organisasi yang di alami oleh anggotanya, mempengaruhi perilakunya, dan dapat dideskripsikan dengan nilai-nilai karakteristik organisasi. Menurut Owens (dalam Soetopo, 2012) menyatakan bahwa "organizational climate is the study of perceptions that individuals have of various aspects of the environtment in the organization". Dengan demikian pengkajian iklim organisasi dapat dilakukan dengan menggali data dari persepsi individu yang ada dalam organisasi.

Menurut Surachim dan Firdaus (2008), iklim organisasi adalah sesuatu yang tidak dapat dilihat atau disentuh namun secara langsung atau tidak langsung mempengaruhi dan membentuk suatu keadaan ataupun kondisi yang diterima oleh semua aspek yang ada di dalam organisasi. Menurut Sari (2009), bahwa Iklim organisasi adalah suatu sistem sosial yang selalu dipengaruhi oleh lingkungan baik internal maupun eksternal. Menurut Halpin (dalam Soetopo, 2012) bahwa iklim organisasi memiliki 8 komponen yang menjadi alat ukur, diantaranya adalah disengagement atau ketidakikutsertaan, hidrance atau halangan, esprit atau semangat, intimacy atau keintiman, aloofness atau keberjarakan, production emphasis atau penekanan pada hasil, thurst atau rasa yakin, dan consideration atau perhatian.

Pengaruh faktor iklim organisasi terhadap OCB menarik untuk dikaji karena menurut Pourkiani et al., (2014), bahwa perilaku OCB akan terjadi jika iklim organisasi baik. Artinya iklim organisasi yang tinggi akan membentuk OCB yang tinggi, begitupun sebaliknya iklim organisasi yang rendah akan terbentuk OCB yang rendah pula. Menurut hasil penelitian Miner (dalam Soetopo, 2012) menunjukkan bahwa manajer yang bekerja dalam iklim organisasi yang terbuka menunjukkan pekerjaan yang lebih baik daripada manajer yang bekerja dalam iklim tertutup.

Selanjutnya hasil penelitian Subramani, Jan, Gaur, dan Vinodh (2016), mengemukakan bahwa iklim organisasi secara positif berdampak pada OCB. Dalam mengubah lingkungan 
tradisional menjadi lingkungan yang dinamis dan efisien, perilaku kewargaan organisasi sebagai salah satu konsep baru dari manajemen perilaku organisasi yang menempatkan penekanan pada karyawan dan iklim organisasi. Namun dalam penelitian lain menemukan bahwa Iklim organisasi berpengaruh secara tidak langsung terhadap Organizational Citizenship Behavior tetapi terdapat variable lain yang memediasi, yaitu psychological capital (Qadeer \& Jaffery, 2014).

Fenomena tentang iklim organisasi yang terlihat dari perilaku sebagian pegawai BPKAD, dimana para pegawai staf yang merasa segan terhadap pimpinannya, yang kemudian tercipta suasana kurang menyenangkan dalam organisasi. Suasana yang kurang menyenangkan menyebabkan perasaan tidak nyaman dari pegawai, akhirnya perilaku sukarela saling menolong dan kemauan bekerja lebih dari deskripsi pekerjaan yang ditetapkan dalam organisasi akan sulit untuk dilakukan oleh pegawai. Hal ini senada dengan yang dikemukakan oleh Prihatsanti dan Dewi (2010), bahwa jika iklim organisasi dipersepsikan secara positif, maka individu sebagai anggota organisasi akan sukarela melaksanakan pekerjaannya dalam organisasi melebihi apa yang diharapkan dan dilaksanakan.

Faktor penting lain yang berperan dalam pembentukan OCB, yaitu keterlibatan kerja. Menurut Robbins dan Judge (2015), mendefinisikan keterlibatan kerja adalah tingkat dimana seseorang mengidentifikasi dengan sebuah pekerjaan, secara aktif berpartisipasi didalamnya, dan mempertimbangkan kinerja penting bagi nilai diri. Keterlibatan kerja atau keterlibatan pegawai berarti keterlibatan mental dan emosional daripada sekedar aktivitas otot pegawai, yaitu keterlibatan menyeluruh seseorang, tidak sekedar keterampilannya. Keterlibatan ini bersifat psikologis daripada fisik (Kaswan, 2015). Menurut Rashidi, Gheisari, Farokhian (2014), bahwa keterlibatan kerja dapat didefinisikan sebagai keterlibatan orang dalam pekerjaan mereka. Orang yang terlibat dalam pekerjaan mereka, dikenal dengan orang yang termotivasi. Mereka cenderung untuk bekerja lebih keras dan lebih efisien daripada yang lain dan lebih mungkin bagi mereka untuk mencapai hasil prestasi dan diperhatikan organisasi. Menurut Kimbal, Sendow, Adare, (2015), bahwa keterlibatan kerja adalah tingkatan seberapa jauh karyawan memihak pada tugas pekerjaan yang mereka terima dengan terlibat dalam setiap aktivitas positif yang berhubungan dengan kesuksesan organisasi. Menurut Lodahl dan Kejner's (dalam Govender \& Parumasur, 2010), bahwa untuk mengukur keterlibatan kerja (Job Involvement) terdapat 4 subdimensi yang penting, yaitu respon pada pekerjaan; ekspresi keterlibatan kerja; bertanggungjawab terhadap pekerjaan; dan perasaan bersalah dan ketidakhadiran.

Pengaruh faktor keterlibatan kerja terhadap OCB juga menarik untuk dikaji karena menurut Rashidi, et al. (2014), bahwa keterlibatan kerja dalam performa yang baik akan memunculkan OCB. Artinya tingginya keterlibatan kerja dapat mendorong OCB pegawai yang tinggi dalam organisasi, begitupun sebaliknya rendahnya keterlibatan kerja dapat menciptakan OCB pegawai yang rendah. Hal ini juga ditegaskan oleh Saxena dan Saxena (2015), hasil penelitian mereka 
mengidikasikan bahwa ada dampak yang signifikan dari keterlibatan kerja pada Organizational Citizenship Behavior.

Fenomena tentang keterlibatan kerja pegawai BPKAD yang terlihat, dimana tidak semua pegawai BPKAD memiliki ketekunan dalam bekerja, kurang paham terhadap apa yang dikerjakan, kurang terampil dalam bekerja, dan kurangnya inisiatif dalam menyelesaikan pekerjaan. Senada dengan pendapat Saputra, Yono, dan Irvianto (2013), bahwa karyawan yang memiliki keterlibatan kerja yang tinggi, karyawan tersebut akan benar-benar serius menangani pekerjaannya. Sebaliknya jika karyawan yang kurang terlibat dalam pekerjaannya, karyawan tersebut hanya bekerja secara rutinitas. Sehingga jika karyawan memiliki keterlibatan kerja yang baik, OCB juga akan meningkat.

Dengan demikian, maka diketahui bahwa peran iklim organisasi dan keterlibatan kerja penting untuk mendorong pembentukan OCB pegawai dalam organisasi, khususnya pada BPKAD Kabupaten Banggai Laut Provinsi Sulawesi Tengah. Guna memperdalam bahasan permasalahan, maka dapat dirumuskan masalahnya, yaitu apakah ada pengaruh iklim organisasi dan keterlibatan kerja secara simultan terhadap OCB Pegawai BPKAD Kabupaten Banggai Laut Provinsi Sulawesi Tengah?

\section{METODE}

Penelitian ini melibatkan satu variabel tergantung, yaitu OCB dan dua variabel bebas yaitu iklim organisasi dan keterlibatan kerja. Subjek penelitian ini adalah pegawai BPKAD Kabupaten Banggai Laut Provinsi Sulawesi Tengah. Subjek dalam penelitian ini sebanyak 40 orang. Data setiap variabel diambil dari hasil pengukuran skala masing-masing (skala A untuk variable iklim organisasi, skala B untuk variable keterlibatan kerja, dan skala C untuk OCB).

Variabel OCB diukur dengan menggunakan skala yang dibuat oleh peneliti berdasarkan aspek dari Organ (dalam Kaswan, 2015) yang terdiri dari aspek altruism, conscientiousness, sportsmanship, courtesy, dan civic virtue.

Iklim organisasi diukur dengan menggunakan skala yang dibuat oleh peneliti berdasarkan aspek dari Halpin (dalam Soetopo, 2012) yang terdiri dari komponen disengagement atau ketidakikutsertaan, hindrance atau halangan, esprit atau semangat, intimacy atau keintiman, aloofness atau keberjarakan, productionemphasis atau penekanan pada hasil, thurst atau rasa yakin, dan consideration atau perhatian, sebagaimana terungkap dalam skala iklim organisasi. Variabel keterlibatan kerja diukur dengan menggunakan skala yang dibuat oleh peneliti berdasarkan aspek dari Lodahl dan Kejner's (dalam Govender dan Parumasur, 2010), yang terdiri dari dimensi respon pada pekerjaan, ekspresi keterlibatan kerja, bertanggungjawab terhadap pekerjaan, dan perasaan bersalah terhadap pekerjaan yang belum selesai dan ketidakhadiran.

Sebelum skala digunakan dalam penelitian, peneliti melakukan uji validitas dan reliabilitas. Untuk Skala Iklim Organisasi, validitas diukur dari korelasi antara setiap skor butir dengan skor 
totalnya. Hasil uji validitas menyatakan bahwa sejumlah pernyataan valid bergerak dengan nilai Indeks Daya Beda 0,713 hingga sebesar 0,308. Hasil uji reliabilitas menunjukkan angka sebesar 0,910. Sedangkan untuk Skala Keterlibatan Kerja, validitas diukur dari korelasi antara setiap skor butir dengan skor totalnya. Hasil uji validitas menyatakan bahwa sejumlah pernyataan valid bergerak dengan nilai Indeks Daya Beda 0,795 hingga sebesar 0,311. Hasil uji reliabilitas menunjukkan angka sebesar 0,935. Skala OCB, validitas diukur dari korelasi antara setiap skor butir dengan skor totalnya. Hasil uji validitas menyatakan bahwa sejumlah pernyataan valid bergerak dengan nilai Indeks Daya Beda 0,790 hingga sebesar 0,312. Hasil uji reliabilitas menunjukkan angka sebesar 0,922 .

Dalam hal ini, peneliti melakukan uji coba dengan jumlah sampel sebanyak 30 pegawai BPKAD yang berbeda dengan subjek penelitian. Koefisien reliabilitas $\left(\mathrm{r}_{\mathrm{xx}^{\prime}}\right)$ berada dalam rentang angka dari 0 sampai dengan 1,00. Aitem-aitem dalam penelitian ini dikatakan memiliki reliabilitas tinggi jika koefisien >0,60. Hasil uji validitas untuk variabel bebas iklim organisasi yang tampak pada tabel output Item-Total Statistics bahwa dari 48 pernyataan sebelum uji coba terdapat 14 pernyataan yang tidak valid setelah uji coba, yaitu 1, 13, 15, 25, 27, 29, 30, 34, 35, 37, 39, 41, 44, dan 48. Sedangkan sisa penyataaan sebanyak 34 dikatakan valid dan siap digunakan untuk penelitian. Hasil uji reliabilitas yang tampak pada tabel output Reliability Statistics menunjukkan angka sebesar 0,910, sehingga item-item dalam penelitian ini dikatakan reliabel.

Hasil uji validitas untuk variabel bebas keterlibatan kerja yang tampak pada tabel output Item-Total Statistics bahwa dari 48 pernyataan sebelum uji coba terdapat 13 pernyataan yang tidak valid setelah uji coba, yaitu 2, 3, 6, 11, 13, 14, 20, 28, 31, 32, 33, 36, dan 38. Sedangkan sisa penyataaan sebanyak 35 dikatakan valid dan siap digunakan untuk penelitian. Hasil uji reliabilitas yang tampak pada tabel output Reliability Statistics menunjukkan angka sebesar 0,935, sehingga item-item dalam penelitian ini dikatakan reliabel. Hasil uji validitas untuk variabel terikat OCB yang tampak pada tabel output Item-Total Statistics bahwa dari 50 pernyataan sebelum uji coba terdapat 17 pernyataan yang tidak valid setelah uji coba, yaitu 1, 9, 17, 19, 20, 22, 23, 24, 25, 26, $32,34,37,38,43,47$, dan 50. Sedangkan sisa penyataaan sebanyak 33 pernyataan dikatakan valid dan siap digunakan untuk penelitian. Hasil uji reliabilitas yang tampak pada tabel output Reliability Statistics menunjukkan angka sebesar 0,922, sehingga item-item dalam penelitian ini dikatakan reliabel. Analisis data menggunakan pendekatan statistik, khususnya teknik analisis regresi linear berganda.

\section{HASIL DAN PEMBAHASAN}

Sebelum malakukan pengujian hipotesis dengan menggunakan analisis regresi linear berganda, terlebih dahulu dilakukan uji prasyarat yang meliputi uji normalitas, uji multikolinearitas, uji heteroskedastisitas, dan uji autokorelasi. Selanjutnya dapat diuaraikan sebagai berikut. 
Uji Normalitas

Hasil uji normalitas didasarkan pada nilai signifikansi dengan ketentuan $>0,05$, maka data dapat dikatakan normal. Berdasarkan hasil analisis pada tabel output one-sample kolmogorovsmirnov menunjukkan bahwa nilai signifikansi sebesar $0,747>0,05$, hal ini berarti bahwa semua data terdistribusi normal.

Uji Multikolinearitas

Hasil analisis uji multikolinearitas didasarkan pada nilai Tolerance $>0,1$ dan nilai $V I F<10$. Berdasarkan hasil analisis pada tabel output coefficients ${ }^{a}$, maka diketahui seluruh variabel bebas memiliki nilai tolerance sebesar 0,606 dan nilai VIF menunjukkan sebesar 1,649. Dengan demikian disimpulkan bahwa model regresi ini terbebas dari gejala multikolinearitas antar variabel bebas.

Uji Heteroskedastisitas

Hasil analisis uji heteroskedastisitas didasarkan pada nilai signifikansi $>0,05$. Berdasarkan hasil uji heteroskedastisitas pada tabel output coefficients ${ }^{a}$, menunjukkan bahwa nilai signifikansi iklim organisasi sebesar 0,712 dan signifikansi keterlibatan kerja sebesar 0,563. Maka dapat disimpulkan bahwa model regresi ini bebas dari masalah heterokedastisitas.

\section{Uji Autokorelasi}

Hasil analisis uji autokorelasi didasarkan pada angka Durbin-Watson harus berada diantara 2 dengan 2. Berdasarkan hasil analisis uji autokorelasi pada tabel output model summary ${ }^{b}$, diketahui bahwa nilai Durbin-Watson adalah 1,415 maka disimpulkan bahwa model regresi ini terbebas dari masalah autokorelasi.

Untuk menguji hipotesis menggunakan analisis uji regresi ganda. Hasil uji regresi ganda didasarkan pada nilai signifikansi $\mathrm{F}<0,05$ untuk menjawab hipotesis mayor nomor 1 , yaitu ada pengaruh yang signifikan secara simultan iklim organisasi dan keterlibatan kerja terhadap OCB. Berdasarkan hasil analisis yang tampak pada tabel output ANOVA ${ }^{b}$, maka dapat diketahui bahwa nilai signifikansi 0,00. Dengan demikian disimpulkan bahwa hipotesis mayor nomor 1 penelitian ini diterima.

Hasil uji t didasarkan pada nilai signifikansi $<0,05$ untuk menjawab hipotesis minor $2 \mathrm{a}$, yaitu ada pengaruh iklim secara positif dan signifikan terhadap OCB, dan $2 b$, yaitu ada pengaruh keterlibatan kerja secara positif dan signifikan terhadap OCB. Berdasarkan hasil analisis yang tampak pada tabel output coefficient ${ }^{a}$, maka diketahui nilai signifikansi sebesar 0,01. Variabel keterlibatan kerja memiliki nilai signifikansi sebesar 0,00. Sehingga dengan demikian, hipotesis minor $2 \mathrm{a}$ dan $2 \mathrm{~b}$ dalam penelitian ini diterima.

Hasil uji determinasi $\left(\mathrm{R}^{2}\right)$ untuk mengetahui besarnya sumbangan pengaruh iklim organisasi dan keterlibatan kerja secara simultan terhadap OCB. Berdasarkan hasil analisis yang tampak pada tabel output model summary, maka diketahui nilai $\mathbf{R}_{\text {square }}$ sebesar 0,634. Artinya bahwa persentase sumbangan pengaruh iklim organisasi dan keterlibatan kerja terhadap OCB sebesar 63,4\%, 
sedangkan pengaruh dari faktor lain terhadap OCB yang tidak termasuk dalam penelitian ini, seperti karakteristik pekerjaan, kepribadian, motivasi, dan kepemimpinan sebesar 36,6\%.

Di samping itu, nilai $\mathrm{R}$ juga dalam regresi linear berganda yang menunjukkan nilai korelasi berganda perlu guna mengetahui seberapa eratnya hubungan iklim organisasi dan keterlibatan kerja terhadap OCB. Nilai R berkisar antara 0 sampai 1, jika mendekati 1 maka hubungan semakin erat, tetapi jika mendekati 0 maka hubungan semakin lemah. Nilai $\mathrm{R}$ didapatkan berdasarkan hasil analisis yang tampak pada tabel output model summary sebesar 0,796, artinya korelasi antara iklim organisasi dan keterlibatan kerja terhadap OCB sebesar 0,796. Hal ini berarti terjadi hubungan yang erat karena nilai mendekati 1.

Perbandingan koefisien regresi untuk menjawab hipotesis nomor 3, yaitu pengaruh keterlibatan kerja lebih besar daripada iklim organisasi terhadap OCB. Berdasarkan hasil analisis yang tampak pada tabel output coefficient ${ }^{a}$, maka diketahui bahwa koefisien regresi iklim organisasi $\left(b_{1}\right)$ sebesar 0,349 dan koefisien regresi keterlibatan kerja $\left(b_{2}\right)$ sebesar 0,529 , maka disimpulkan bahwa hipotesis nomor 3 dalam penelitian ini diterima.

Berdasarkan hasil penelitian, maka dapat diketahui bahwa iklim organisasi dan keterlibatan kerja secara simultan berpengaruh terhadap OCB. Sehingga hasil penelitian ini mendukung hipotesis mayor yang diajukan, yaitu ada pengaruh yang signifikan iklim organisasi dan keterlibatan kerja secara simultan terhadap OCB. Hasil penelitian ini sesuai dengan penelitian sebelumnya oleh Allameh, Shahriari, Mansoori (2012) yang menyatakan bahwa secara signifikan sikap kerja, iklim organisasi, dan keterlibatan pegawai sebagai antesenden dari OCB. Dalam penelitian sebelumnya tersebut tidak menyebutkan sikap kerja karyawan secara spesifik, seperti yang dinyatakan oleh Robbins \& Judge (dalam Kaswan, 2015) bahwa sikap kerja terdiri dari kepuasan kerja, komitmen organisasi, keterlibatan kerja, engagement pegawai, semangat kerja, dukungan organisasi, keadilan organisasi, dan OCB. Sementara dalam penelitian ini, menggunakan salah satu diantara beberapa sikap kerja tersebut, yaitu keterlibatan kerja. Dengan demikian, dapat dikatakan bahwa hasil penelitian ini mendukung penelitian sebelumnya, yaitu iklim organisasi dan keterlibatan kerja secara simultan berpengaruh signifikan terhadap OCB. Dalam hal ini, organisasi dengan iklim yang terbuka akan memberikan kesempatan kepada pegawai untuk berkembang, seperti mendapat kepercayaan dari atasan dan saling menghargai satu sama lain (Soetopo, 2012). Artinya dengan iklim organisasi yang terbuka akan cenderung memberikan kesempatan kepada pegawai untuk ikut berpartisipasi dalam setiap pengambilan keputusan serta menghargai pendapat satu sama lain dalam organisasi. Iklim organisasi yang terbuka dapat menimbulkan perasaan terlibat pegawai terhadap pekerjaannya dalam organisasi, akhirnya mereka merasakan memiliki tempat kerja yang baik dan lebih diterima. Hal ini akan cenderung mendorong rasa kebersamaan pegawai dan saling membantu dalam bekerja, walaupun diluar job descrpition. Berdasarkan penjelasan diatas, maka dapat disimpulkan bahwa konsekuensi logis dari adanya iklim organisasi 
yang baik dan keterlibatan kerja yang baik dapat mempengaruhi perilaku OCB pegawai dalam kantor BPKAD.

Berdasarkan hasil penelitian menunjukkan bahwa iklim organisasi berpengaruh secara positif dan signifikan terhadap OCB. Hasil penelitian ini mendukung hipotesis minor 2a yang diajukan dalam penelitian ini, yaitu ada pengaruh iklim organisasi secara positif dan signifikan terhadap OCB. Hasil penelitian ini senada dengan beberapa penelitian sebelumnya bahwa iklim organisasi secara positif dan signifikan berpengaruh terhadap OCB (Subramani, Jan, Gaur, \& Vinodh, N., 2016 \& Qadeer \& Jaffery, 2014). Menurut hasil penelitian Miner (dalam Soetopo, 2012) menunjukkan bahwa manajer yang bekerja dalam iklim organisasi yang terbuka menunjukkan pekerjaan yang lebih baik daripada manajer yang bekerja dalam iklim tertutup. Artinya dengan iklim organisasi yang terbuka dan dirasakan langsung oleh pegawai dalam kantor BPKAD dapat menciptakan rasa aman dan nyaman saat bekerja sehingga dapat mendorong para pegawai untuk bekerja lebih baik dari yang diharapkan. Begitupun sebaliknya, pada kondisi iklim organisasi yang tertutup, pegawai sulit untuk bekerja sama dan saling membantu satu sama lain dalam menyelesaikan pekerjaan sebab para pegawai merasa terbatasnya kebebasan untuk berekspresi dalam bekerja. Pegawai yang merasa berada didalam iklim organisasi yang terbuka akan merasa senang saat bekerja, dan hal ini akan berdampak pada terbentuknya perilaku OCB pegawai dalam organisasi. Dengan demikian dapat disimpulkan bahwa konsekuensi logis dari iklim organisasi berpengaruh terhadap OCB pegawai dalam organisasi, khususnya pada kantor BPKAD.

Berdasarkan hasil penelitian, diketahui bahwa keterlibatan kerja berpengaruh secara positif dan signifikan terhadap OCB. Hasil penelitian ini mendukung hipotesis minor $2 \mathrm{~b}$ yang diajukan dalam penelitian ini, yaitu ada pengaruh keterlibatan kerja secara positif dan signifikan terhadap OCB. Hasil penelitian ini sejalan dengan penelitian sebelumnya oleh Saputra., et al. (2013) yang menunjukkan bahwa keterlibatan kerja memiliki pengaruh yang positif dan signifikan terhadap Organizational Citizenship Behavior. Artinya karyawan yang memiliki keterlibatan kerja yang tinggi, karyawan tersebut akan benar-benar serius menangani pekerjaannya dengan demikian dapat mengurangi absensinya, dan dari tingkat pengunduran diri. Sebaliknya jika karyawan yang kurang terlibat dalam pekerjaannya, karyawan tersebut hanya bekerja secara rutinitas. Sehingga jika karyawan memiliki keterlibatan kerja yang baik, Organizational Citizenship Behavior juga akan meningkat. Begitu juga sebaliknya jika karyawan memiliki keterlibatan kerja yang rendah, organizational citizenship behavior juga akan menurun.

Hasil uji koefisien determinasi $\left(\mathrm{R}^{2}\right)$ menunjukkan bahwa sumbangan pengaruh iklim organisasi dan keterlibatan kerja secara simultan terhadap OCB sebesar 63,4\%, sedangkan pengaruh dari faktor lain terhadap OCB yang tidak termasuk dalam penelitian ini, seperti karakteristik pekerjaan, kepribadian, motivasi, dan kepemimpinan sebesar 36,6\%. Sementara nilai $\mathrm{R}$ yang diperoleh sebesar 0,796 . Hali ini mengartikan bahwa ditemukan hubungan yang erat antara iklim organisasi dan keterlibatan kerja terhadap OCB. Dengan demikian disimpulkan bahwa iklim 
organisasi dan keterlibatan kerja pada kantor BPKAD Kabupaten Banggai Laut Provinsi Sulawesi Tengah dapat dipercaya sebagai acuan untuk memprediksi munculnya OCB pegawai.

Hasil perbandingan koefisien regresi menunjukkan pengaruh keterlibatan kerja $\left(b_{2}\right)$ lebih besar daripada iklim organisasi $\left(b_{1}\right)$. Hasil penelitian ini mendukung hipotesis nomor 3 yang diajukan dalam penelitian ini, yaitu pengaruh keterlibatan kerja lebih besar daripada iklim organisasi terhadap OCB. Artinya hasil penelitian ini menegaskan bahwa faktor keterlibatan kerja paling dominan berpengaruh terhadap OCB pegawai dalam kantor BPKAD Kabupaten Banggai Laut Provinsi Sulawesi Tengah. Senada dengan yang dikemukakan oleh Robbins dan Judge (2015), bahwa level tinggi dari keterlibatan kerja maupun pemberdayaan psikologis berhubungan positif dengan sikap kewargaan organisasi atau OCB.

\section{KESIMPULAN}

Berdasarkan hasil penelitian dan pembahasan, maka dapat disimpulkan bahwa iklim organisasi dan keterlibatan kerja secara simultan maupun parsial berpengaruh signifikan terhadap OCB. Artinya apabila iklim organisasi dan keterlibatan kerja meningkat, khususnya pada kantor BPKAD maka OCB pegawai pula akan meningkat. Sebaliknya jika iklim organisasi dan keterlibatan kerja rendah, maka OCB akan menurun. Sumbangan pengaruh iklim organisasi dan keterlibatan kerja secara simultan terhadap OCB pegawai di BPKAD, yaitu sebesar 63,4\%. Sedangkan sumbangan pengaruh variabel lain diluar penelitian ini, seperti karakteristik pekerjaan, kepribadian, motivasi, dan kepemimpinan sebesar 36,6\%. Pengaruh keterlibatan kerja lebih besar dan signifikan daripada iklim organisasi terhadap OCB. Artinya bahwa keterlibatan kerja yang lebih dominan dalam mempengaruhi OCB daripada iklim organisasi pada BPKAD.

\section{DAFTAR PUSTAKA}

Allameh, S., Shahriari, M., \& Mansoori, H. (2012). Investigating employee's attitude toward organization, organizational climate and employee's engagement as antecedents of organizational citizenship behavior. Australian Journal of Basic and Applied Sciences, 6(8), 384-393.

Bianca, A., \& Susihono, W. (2012). Pengaruh iklim organisasi dan pengembangan karir terhadap kepuasan kerja karyawan. Spektrum Industri, 10(2), 108-199.

Govender, S., \& Parumasur, S. (2010). The relationship between employee motivation and job involvement. SAJEMS NS, 13(3), 237-253.

Howe, D. (2015). Empati: Makna dan pentingnya. Yogyakarta: Pustaka Pelajar.

Kaswan. (2015). Sikap kerja, dari teori dan implementasi sampai bukti. Bandung: Alfabeta.

Kimbal, F., Sendow, G., \& Adare, D. (2015). Beban kerja, organizational citizenship behavior, dan keterlibatan kerja pengaruhnya terhadap kinerja karyawan PT. PLN (Persero) wilayah Suluttenggo Area Manado. Jurnal EMBA, 3(2), 1061-1072.

Murugesan, S., Raja, N., \& Kannan, M. (2013). Perceived organisational climate correlates organisational citizenship behaviour: A study among the software professionals. American International Journal of Research in Humanities, Arts and Social Sciences (AIJRHASS), 3(2), 209- 216. 
Pourkiani, M., Farokhian, A., \& Gheisari, F. (2014). Explaining the relationship between organizational climate, organizational commitment and organizational citizenship behavior among employees of Khuzestan gas company. Indian Journal of Fundamental and Applied Life Sciences, 4(S3), 282-290.

Prihatsanti, U., \& Dewi, K,S. (2010). Hubungan antara iklim organisasi dan organizational citizenship behavior (ocb) pada guru sd negeri di kecamatan Mojolaban Sukoharjo. Jurnal Psikologi Undip, 7(1), 11-17.

Qadeer, F., \& Jaffery, H. (2014). Mediation of psychological capital between organizational climate and organizational citizenship behavior. Pakistan Journal of Commerce and Social Sciences (Pak J Commer Soc Sci), 8(2), 453- 470.

Rashidi, R., Gheisari, F., Farokhian, A. (2014). explaining the relationship between organizational commitment, job involvement and organizational citizenship behavior among employees of Khuzestan Gas Company. Indian Journal of Fundamental and Applied Life Sciences, 4(S4), $150-158$.

Robbins. P., \& Judge. A. (2015). Perilaku organisasi, Edisi 16. Jakarta: Salemba Empat.

Saputra, A., Yono, L., \& Irvianto, L. (2013). Analisis pengaruh keterlibatan kerja dan kepuasan kerja terhadap organizational citizenship behavior di PT Prima Graphia Digital. Binus Business Review, 4(2), 897-903.

Sari, E. (2009). Pengaruh kompensasi dan iklim organisasi terhadap kepuasan kerja. Jurnal Ilmu Administrasi dan Organisasi, 16(1), 18-24.

Saxena, S., \& R. Saxena. (2015). Impact of job involvement and organizational commitment on organizational citizenship behavior. Int. J. Manag. Bus. Res., 5(1), 19-30.

Soetopo, H. (2012). Perilaku organisasi. Bandung: PT. Remaja Rosdakarya.

Subramani, A., Jan, N., Gaur, M., \& Vinodh, N. (2016). Impact of organizational climate on organizational citizenship behaviour with respect to automotive industries at ambattur industrial estate, Chennai. IJABER, 13(8), 97-114.

Sudarmanto. (2014). Kinerja dan pengembangan kompetensi sdm: Teori, dimensi pengukuran, dan implementasi dalam organisasi. Yogyakarta: Pustaka Pelajar.

Surachim, A., \& Firdaus, T. (2008). Pengaruh iklim organisasi terhadap kepuasan kerja karyawan pada divisi pharmaserve di PT Combiohar Jakarta. Jurnal Pendidikan Manajemen Bisnis, $7(13)$. 